Situs Jurnal : $\underline{\text { http://ejournal.stiepancasetia.ac.id/index.php/jieb }}$

Jilid 5 Nomor 3 November 2019

Hal 435 - 442

\title{
PENGARUH INFLASI, GROSS DOMESTIC PRODUCT DAN SUKU BUNGA TERHADAP HARGA SAHAM PERUSAHAAN PROPERTI YANG TERDAFTAR DI BURSA EFEK INDONESIA
}

\section{Maria Anastasia*}

Abstract: Accounting Department of Banjarmasin Pancasetia College of Economics, 2018, Influence of Inflation, Gross Domestic Product, and Interest Rates on the Company's Share Price on the Indonesia Stock Exchange. This study aims to determine the magnitude of inflation, gross domestic product and interest rates both partially and simultaneously and the effect on share ownership in the Indonesia Stock Exchange. The sample in this study are 43 property companies that use on the Indonesia Stock Exchange. The data used are income data, inflation data, Gross Domestic Product data, and interest rate data for the period 2015 to 2017. Based on the results of the $t$ test, it is seen that the Gross Domestic Product is partial to the shares in property companies, while inflation and interest rates are not the same. Based on the results of the Fedia Test, Inflation, Gross Domestic Product, and interest rates simultaneously. From the results of the $t$ test and can be searched is between inflation, gross domestic product and interest rates relating to the Gross Domestic Product Variable.

Keywords: Inflation, Gross Domestic Product, interest rates, and property stock prices

Abstrak: Penelitian ini bertujuan untuk mengetahui besaran pengaruh Inflasi, Gross domestic Product dan suku bunga baik secara parsial maupun Simultan dan pengaruh Dominan terhadap harga saham perusahaan properti yang terdaftar di Bursa efek Indonesia. Sampel dalam penelitian ini adalah 43 perusahaan properti yang tercatat di Bursa efek Indonesia. Data yang digunakan adalah harga saham perusahaan properti, data Inflasi, data Gross Domestic Product, dan data suku bunga pada periode 2015 sampai 2017. Berdasarkan hasil Uji t diketahui bahwa Gross Domestic Product secara parsial berpengaruh terhadap harga saham pada perusahaan properti, sedangkan Inflasi dan suku bunga secara parsial tidak berpengaruh terhadap harga saham pada perusahaan properti. Berdasarkan hasil Uji F diketahui bahwa Inflasi, Gross domestic Product, dan suku bunga secara simultan berpengaruh terhadap harga saham perusahaan properti. Dari hasil Uji t juga dapat diketahui bahwa diantara inflasi, Gross domestic Product dan suku bunga yang mempunyai pengaruh Dominan terhadap harga saham properti ditunjukkan oleh Variabel Gross Domestic Product.

Kata kunci: Inflasi, Gross Domestic Product, suku bunga, dan harga saham properti.

\section{Latar Belakang}

Menurut Hafiyyan (2018) tingginya harga Properti saat ini membuat orang-orang pada Zaman sekarang ini sulit memiliki rumah. Untuk menghindari kekhawatiran inflasi akan berdampak bagi kondisi keuangan, maka sebaiknya investasi diarahkan pada sektor riil. Kontribusi konsumsi rumah tangga terhadap Produk Domestik Bruto (PDB) masih cenderung kuat kedepan, jika PDB naik maka sektor yang mendapat sentimen positif adalah Properti. Ketika BI menaikkan suku bunga maka, maka ada kemungkinan Pasar Saham akan 
ditinggalkan, Investor akan lebih suka menabung yang memberikan bunga menarik dengan risiko rendah dari pada di Pasar Saham dengan risiko yang lebih tinggi

\section{Kajian Literatur}

Real estate maupun properti memiliki pengertian yang sama, yaitu hak kepemilikan atas tanah dan bangunan yang didirikan diatasnya (Hartanto:2018). Inflasi merupakan suatu kejadian yang menggambarkan situasi dan kondisi dimana harga barang mengalami kenaikan dan nilai mata uang mengalami pelemahan (Fahmi:2015).

Menurut Mankiw (2016) Gross Domestic Product merupakan nilai produk dari semua barang dan jasa akhir (final) yang diproduksi dalam sebuah negara pada suatu periode tertentu. Suku Bunga merupakan balas jasa yang diberikan oleh Bank yang berdasarkan prinsip konvensional kepada nasabah yang membeli dan menjual produknya (Kasmir:2014). Pasar Modal adalah tempat untuk mentransaksikan modal jangka panjang, dimana permintaan diwakili oleh perusahaan penerbit surat berharga dan penawaran diwakili oleh para Investor (Widoadmodjo:2015).

\section{Metode Penelitian}

Jenis penelitian kuantitatif, dengan metode pengumpulan data dengan studi pustaka. Tekhnik yang digunakan dalam pengumpulan data adalah dokumentasi dari data yang dipublikasikan oleh Bursa Efek Indonesia. Sampel penelitian terdiri dari 43 perusahaan properti yang terdaftar di bursa efek. Berikut tekhnik analisis data yang digunakan dalam penelitian.

1. Pengujian Asumsi Klasik

Untuk mendapatkan parameter-parameter estimasi dari model dinamis yang dipakai, dalam penelitian inidigunakan metode penaksiran OLS (Ordinary Least Square).

a. Uji Normalitas

Uji Normalitas dilakukan untuk mengetahui bagaimana sebaran sebuah data, cara Uji Normalitas dilakukan dengan Uji sahapiro wilk, Kolmogrov Smirnov atau dengan metode gafik, dalam penelitian ini menggunakan Uji Kolmogrov Smirnov sehingga apabila hasil uji statistik adalah diterima Ho, maka disimpulkan data berdistribusi normal (Ghozali:2013).

b. Uji Heteroskedastisitas

Uji Heteroskedastisitas bertujuan untuk menguji apakah dalam model regresi terjadi ketidaksamaan variance dari residual satu pengamatan ke pengamatan lain. Jika Variance dari residual dari satu pengamtan ke pengamatan yang lain tetap maka disebut homokedastisitas. Dalam penelitian ini digunakan Uji Spearman Rho digunakan untuk uji Bivariate Asosiatif beberapa Variabel bebas atau Indevenden (Ghozali:2013)

c. Uji Autokorelasi

Uji Autokorelasi bertujuan untuk menguji apakah dalam model regresi linier ada korelasi antara kesalahan pengganggu pada periode $t$ dengan kesalahan pengganggu pada periode t-1 (sebelumnya). Jika terjadi korelasi, maka dinamakan ada problem korelasi. Pengujian ini menggunakan Durbin Watson. Hasil pengujian Autokorelasi dengan metode Cochrane Ocrutt dihasilkan nilai Durbin Watson sbesar 1,842. Selanjutnya nilai DW dibandingkan dengan nilai du dan 4-du (Ghozali:2013).

2. Regresi Linier Berganda

(Ghozali:2013) Analisis regresi adalah metode analisis statistik yang digunakan untuk mengetahui hubungan antara 2 atau lebih variabel kuantitatif sehingga suatu variabel dapat di prediksi dari vaiabel lain.Berikut bentuk persamaan regresi linear berganda yang dikembangkan dalam penelitian ini : 


$$
\begin{array}{lll}
\mathrm{Y}=\mathrm{a}+ & \beta_{1} X_{1}+\beta_{2} X_{2}+\beta_{3} X_{3}+\mathrm{e} \\
\mathrm{Y} & = & \text { Harga saham } \\
\mathrm{a} & = & \text { Konstanta } \\
\beta & = & \text { Koefisien regresi } \\
\mathrm{X}_{1} & = & \text { Inflasi } \\
\mathrm{X}_{2} & & =\quad \text { Gros Domestic Product } \\
\mathrm{X}_{3} & = & \text { Suku Bunga } \\
\mathrm{e} & = & \text { Koefisisen Error }
\end{array}
$$

Berikut adalah serangkaian pengujian Hipotesis yang akan dilakukan dilakukan untuk penelitian ini:

1. Koefesien Determinasi

Digunakan untuk mengetahui seberapa jauh kemampuan suatu penelitian dalam menjelaskan variabel variabel dependent yang ada. Dengan demikian akan diketahui seberapa besar variabel dependent dapat diterangkan oleh variabel independent yang ada. Nilai yang mendekati angka 1 berati variabel independent hampir atau mampu memberikan informasi yang dibutuhkan untuk memprediksi variabel dependent (Ghozali, 2013).

\section{Uji Pengaruh Parsial dengan Uji T}

Uji ini dilakukan untuk mengetahui seberapa jauh variabel independent secara individu dalam menerangkan variabel dependen. Uji statistik t digunakan untuk mengetahui apakah ada perbedaan yan terjadi antar variabel variabel uji terhadap kelompok uji. Dengan test akan didapatkan perhitungan apakah terdapat pengaruh yang signifikan atau tidak. Tahap tahap pengujiannya adalah :

a. Merumuskan hipotesis

b. Menentukan tingkat signifikansi yaitu 0,05 atau $5 \%$

3. Uji Pengaruh Simultan dengan Uji F

Uji ini digunakan untuk mengetahui apakah model regresi linier berganda yang telah didapatkan telah signifikan (telah sesuai untuk menggambarkan pengaruh simultan variabel bebas terhadap variabel terikat). Untuk mengetahui variabel-variabel bebas berpengaruh secara simultan (bersama) terhadap variabel terikat digunakan uji $\mathrm{F}$ dengan tingkat signifikan $\alpha=0,05$. Jika hasil statistik $\mathrm{F}$ pada taraf signifikan $\leq 0,05$ berartivariabelvariabelbebasmempunyai pengaruh yang signifikan secara simultan terhadap variabel terikat dan sebaliknya.

\section{Hasil Penelitian}

Statistik Deskriptif merupakan cara penyajian data yang berhubungan dengan hal-hal yang menguraikan atau memberikan keterangan mengenai suatu data atau keadaan dengan menarik kesimpulan pada kumpulan data yang ada. Dari hasil pengolahan data dengan program SPSS diperoleh hasil seperti pada Tabel 1. 
Tabel 1. Deskriptif Variabel Penelitian

\begin{tabular}{lcrrrr}
\multicolumn{1}{c}{ Descriptive Statistics } & \multicolumn{6}{l}{ Min } & Max & \multicolumn{1}{l}{ Mean } & Std. Deviation \\
\hline Inflasi & 129 & 3.02 & 3.61 & 3.3267 & .24237 \\
\hline GDP & 129 & 4.88 & 5.07 & 4.9933 & .08210 \\
\hline Suku Bunga & 129 & 4.25 & 7.50 & 5.5000 & 1.43444 \\
\hline Saham & 129 & 50 & 36500 & 1749.93 & 4478.132 \\
\hline Valid N (listwise) & 129 & & & &
\end{tabular}

\section{Sumber : Data Diolah menggunakan SPSS 16}

Berdasarkan tabel 1 yang menunjukkan tentang statistik deskriptif data dapat diketahui hal-hal sebagai berikut:

1. Hasil tersebut menunjukkan bahwa besarnya Inflasi dalam penelitian ini berkisar antara 3,02 hingga 3,61 dengan nilai mean 3,3267 dan standart deviasi 0,24237. Nilai standart deviasi tersebut lebih rendah dari mean, yang artinya bahwa data variabel Inflasi pada penelitian ini tidak bervariasi.

2. Hasil tersebut menunjukkan bahwa besarnya GDP yang menjadi sampel penelitian ini berkisar antara 4,88 hingga 5,07 dengan nilai mean 4,9933 dan standart deviasi 0,8210. Nilai standart deviasi terebut lebih rendah dari nilai mean, yang berarti bahwa data variabel GDP pada penelitian ini tidak bervariasi.

3. Hasil tersebut menunjukkan bahwa besarnya tingkat suku bunga yang menjadi sampel dalam penelitian ini berkisar antara 4,25 hingga 7,50 dengan nilai mean 5,5000 dan standart deviasi 1,43444. Nilai standart deviasi tersebut lebih rendah dari nilai mean yang berarti bahwa variabel tingkat suku bunga pada penelitian ini tidak bervariasi.

4. Hasil tersebut menunjukkan bahwa besarnya harga saham perusahaan yang menjadi sampel penelitian ini berkisar antara 50 hingga 36500 dengan nilai mean 1749,93 dan standar deviasi 4478,132. Nilai standart deviasi tersebut lebih besar dari nilai mean, yang berarti bahwa data variabel harga saham pada penelitian ini bervariasi.

Selanjutnya dilakukan Uji Asumsi Klasik untuk memastikan kelayakan kualitas dari model penelitian, sebagai berikut:

1. Uji Normalitas

Tabel 2. Hasil Uji NormalitasKolmogorovSmirnov

One-Sample Kolmogorov-Smirnov Test

\begin{tabular}{|c|c|c|}
\hline & & $\begin{array}{l}\text { Unstandardized } \\
\text { Residual }\end{array}$ \\
\hline $\mathrm{N}$ & & 129 \\
\hline \multirow[t]{2}{*}{ Normal Parameters ${ }^{a}$} & Mean & .0000000 \\
\hline & $\begin{array}{l}\text { Std. } \\
\text { Deviation }\end{array}$ & 1.51141610 \\
\hline \multirow{3}{*}{$\begin{array}{l}\text { Most Extreme } \\
\text { Differences }\end{array}$} & Absolute & .067 \\
\hline & Positive & .067 \\
\hline & Negative & -.066 \\
\hline Kolmogorov-Smirnov Z & & .756 \\
\hline Asymp. Sig. (2-tailed) & & .618 \\
\hline
\end{tabular}


Menurut Sugiyono (2013) berdasarkan tabel 2, maka dapat diketahui bahwa menunjukan nilai signifikan $>0,05$ yaitu 0,618 , maka dapat disimpulkan bahwa residual data pada model regresi berdistribusi normal (asumsi normalitas terpenuhi).

2. Uji Heteroskedastisitas

Tabel 3. Hasil Uji Heteroskedastisitas dengan UjiSpearman Correlations

\begin{tabular}{|c|c|c|c|c|c|c|}
\hline & & & Inflasi & GDP & $\begin{array}{l}\text { Suku } \\
\text { Bunga }\end{array}$ & ABS_RES \\
\hline \multirow[t]{12}{*}{ Spearman's rho } & \multirow[t]{3}{*}{ Inflasi } & $\begin{array}{l}\text { Correlation } \\
\text { Coefficient }\end{array}$ & 1.000 & $.500^{\star *}$ & $-.500^{* *}$ & -.015 \\
\hline & & Sig. (2-tailed) & & .000 & .000 & .866 \\
\hline & & $\mathrm{N}$ & 129 & 129 & 129 & 129 \\
\hline & \multirow[t]{3}{*}{ GDP } & $\begin{array}{l}\text { Correlation } \\
\text { Coefficient }\end{array}$ & $.500^{\star *}$ & 1.000 & $1.000^{\text {** }}$ & -.015 \\
\hline & & Sig. (2-tailed) & .000 & . & . & .868 \\
\hline & & $\mathrm{N}$ & 129 & 129 & 129 & 129 \\
\hline & \multirow[t]{3}{*}{$\begin{array}{l}\text { Suku } \\
\text { Bunga }\end{array}$} & $\begin{array}{l}\text { Correlation } \\
\text { Coefficient }\end{array}$ & $-.500^{* \star}$ & $1.000^{\text {** }}$ & 1.000 & .015 \\
\hline & & Sig. (2-tailed) & .000 & . & . & .868 \\
\hline & & $\mathrm{N}$ & 129 & 129 & 129 & 129 \\
\hline & \multirow[t]{3}{*}{ ABS_RES } & $\begin{array}{l}\text { Correlation } \\
\text { Coefficient }\end{array}$ & -.015 & -.015 & .015 & 1.000 \\
\hline & & Sig. (2-tailed) & .866 & .868 & .868 & \\
\hline & & $\mathrm{N}$ & 129 & 129 & 129 & 129 \\
\hline
\end{tabular}

Menurut Elcom (2012) Berdasarkan tabel 3 dapat diketahui bahwa 3 variabel bebas yang menunjukkan Korelasi rank spearman antara X1 dengan $\mathrm{U}_{\mathrm{t}}$ adalah 0,866, Korelasi rank spearman antara $\mathrm{X} 2$ dengan $\mathrm{U}_{\mathrm{t}}$ adalah 0,868 , Korelasi rank spearman antara $\mathrm{X} 3$ dengan $\mathrm{U}_{\mathrm{t}}$ adalah 0,868 yang berarti lebih besar dari dari 0,05 , dengan demikian dapat disimpulkan bahwa tidak terjadi Heteroskedastisitas dalam model regresi

3. Uji Autokorelasi

Tabel 4. Hasil Uji Autokorelasi

\begin{tabular}{lrrrrr}
\hline \multicolumn{2}{l}{ Model Summary } & & & \\
Model & $\mathrm{R}$ & R Square & $\begin{array}{l}\text { Adjusted R } \\
\text { Square }\end{array}$ & $\begin{array}{l}\text { Std. Error of the } \\
\text { Estimate }\end{array}$ & Durbin-Watson \\
\hline 1 & $.971^{\mathrm{a}}$ & .943 & .942 & 1.52336 & 2.264 \\
\hline Dependent Variable: LN_Y & & & \\
\hline
\end{tabular}

Menurut Sugiyono (2013) Berdasarkan tabel diatas dapat diketahui bahwa model regresi yang terbentuk menunjukan angka di antara 1,65 < DW $<2,35$ sebesar 2,264 sehingga dapat disimpulkan bahwa tidak terjadi autokorelasi dalam model regresi.

Analisis langkah terakhir adalah Analisis Regresi Linear Berganda untuk mengetahui kekuatan pengaruh variabel bebas terhadap variabel terikat. 
Tabel 5. Hasil Estimasi Regresi Berganda

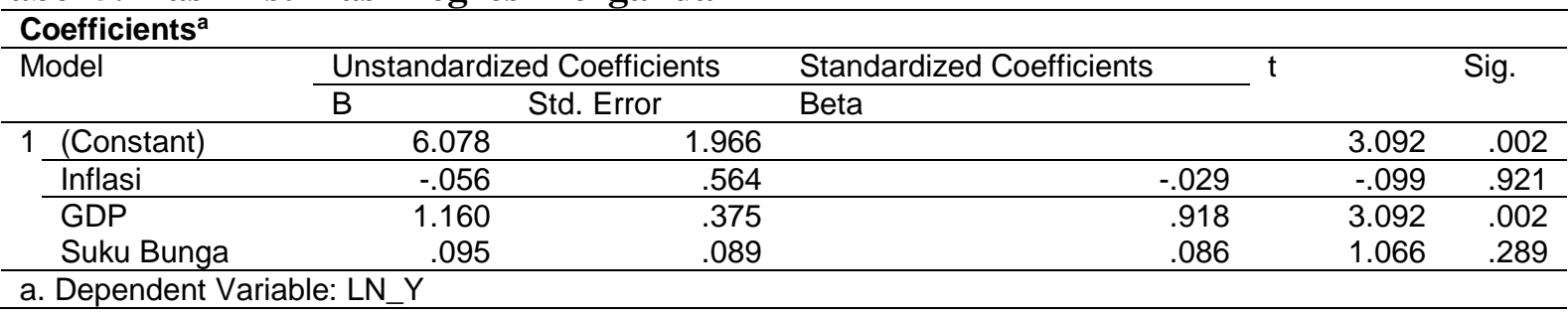

Berdasarkan tabel 5 dapat diketahui bahwa ada atau tidaknya hubungan antara variabel bebas dengan variabel terikat serta dapat menginformasikan besarnya pengaruh variabel bebas terhadap variabel terikat. Dari tabel diperoleh model regresi linier berganda sebagai berikut:

$Y=6,078-0,056 \mathrm{X} 1+1,160 \mathrm{X} 2+0,095 \mathrm{X} 3$

Berdasarkan model regresi di atas dapat dijelaskan bahwa :

1. Nilai a sebesar 6,078 Menunjukkan bahwa jika semua variabel bebas sama dengan nol maka besarnya return saham akan konstan yaitu sebesar 6,078

2. Nilai b1 sebesar - 0,056 Menunjukkan bahwa jika nilai tukar (X1) meningkat satu satuan maka akan menurunkan return saham sebesar - 0,056 satuan dengan asumsi variabel bebas yang lain konstan.

3. Nilai b2 sebesar 1,160 Menunjukkan bahwa jika suku bunga (X2) meningkat satu satuan maka akan menurunkan return saham sebesar 1,160 satuan dengan asumsi variabel bebas yang lain konstan.

4. Nilai b3 sebesar 0,095 Menunjukkan bahwa jika inflasi (X3) meningkat satu satuan maka akan menurunkan return saham sebesar 0,095 satuan dengan asumsi variabel bebas yang lain konstan.

Tabel 6. Hasil Uji Koefisien Determinasi

\begin{tabular}{|c|c|c|c|c|c|}
\hline Mode & nmary ${ }^{b}$ & & & & \\
\hline Model & $\mathrm{R}$ & R Square & Adjusted R Square & Std. Error of the Estimate & Durbin-Watson \\
\hline 1 & $.971^{\mathrm{a}}$ & .943 & .942 & 1.52336 & 2.264 \\
\hline
\end{tabular}

Berdasarkan tabel 6 dapat diketahui bahwa nilai Adjusted R Square menunjukkan angka 0,942 yang berarti hasil tersebut mampu menjelaskan hanya sebesar 94,2\% pengaruh Variabel Indevenden terhadap Variabel Dependen yang dapat diterangkan oleh model penelitian ini dan sisanya sebesar 5,8\% dipengaruhi oleh variabel lain diluar penelitian, sehingga Variabel Independen pada model penelitian ini dapat memberikan informasi akurat yang dibutuhkan untuk memprediksi Variabel Independent.

\section{Tabel 7. Hasil Uji Statistik T}

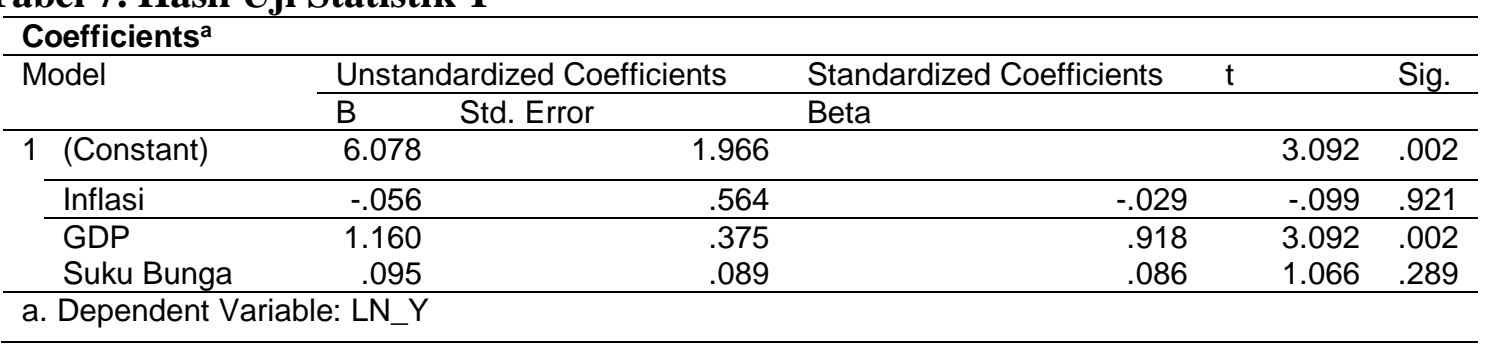


Berdasarkan tabel 7 dapat diketahui bahwa :

1. Inflasi memiliki nilai signifikansi 0,921. Karena nilai sig. $\mathrm{t}>0,05(0,921>0,05)$, maka dapat disimpulkan bahwa secara parsial variabel Inflasi tidak berpengaruh terhadap Harga Saham.

2. GDP memiliki nilai signifikansi 0,002. Karena nilai sig. $\mathrm{t}<0,05(0,002<0,05)$, maka dapat disimpulkan bahwa secara parsial variabel GDP berpengaruh terhadap Harga Saham

3. Suku Bunga memiliki nilai signifikansi 0,289. Karena nilai sig. $t>0,05(0,289>0,05)$, maka dapat disimpulkan bahwa secara parsial variabel Suku Bunga tidak berpengaruh terhadap Harga Saham

Tabel 8. Hasil Uji Statistik F

\begin{tabular}{llllll}
\hline ANOVA $^{\text {c,d }}$ & & & & & \\
\hline Model & $\begin{array}{l}\text { Sum of } \\
\text { Squares }\end{array}$ & Df & Mean Square & F & Sig. \\
\hline 1 Regression & 4844.895 & 3 & 1614.965 & 695.914 & $.000^{\text {a }}$ \\
\hline Residual & 292.400 & 126 & 2.321 & & \\
\hline Total & $5137.295^{\mathrm{b}}$ & 129 & & & \\
\hline
\end{tabular}

a. Dependent Variable: LN_Y

Berdasarkan tabel diatas dapat diketahui bahwa nilai signifikan $0,000<0,05$, sehingga dapat disimpulkan bahwa secara simultan Inflasi, GDP, dan Suku Bunga berpengaruh terhadap harga saham

\section{Kesimpulan dan Keterbatasan Penelitian}

Berdasarkan hasil penelitian dan pembahasan maka dapat ditarik kesimpulan sebagai berikut :

1. Gross Domestic Product secara parsial berpengaruh terhadap harga saham properti, sedangakan Inflasi dan suku bunga secara parsial tidak berpengaruh terhadap harga saham properti.

2. Inflasi, Gross Domestic Product dan suku bunga secara simultan berpengaruh terhadap harga saham properti.

3. Antara Inflasi, Gross Domestic Productdan suku bunga yang mempunyai pengaruh Dominan adalah Gross Domestic Product.

Penelitian ini memiliki keterbatasan yaitu, data yang digunakan hanya data pada periode tiga tahun terakhir dan penelitian ini hanya menggunakan tiga variabel saja, oleh karena itu, Disarankan untuk peneltian berikutnya agar bisa menambahkan variabel faktor-faktor lain yang belum ada pada penelitian ini serta dengan periode yang lebih panjang lagi agar terlihat lebih jelas lagi faktor-faktor yang mempengaruhi perusahaan properti. Berdasarkan hasil penelitian dan simpulan, maka saran-saran yang penulis berikan berkaitan dengan penelitian ini adalah :

1. Sebagai seorang bisa mengambil saham properti sebagai pilihan Investasi, terutama menggunakan faktor GDP serta faktor-faktor ekonomi makro sebagai lainnya.

2. Saham Properti bisa djadikan sebagai Investasi jangka panjang seiring dengan pertumbuhan perekonomian yang secara umum harga saham akan terus meningkat.

3. Sebagai pertimbangan dalam memilih Investasi, Baiknya Investor melihat pergerakkan GDP terutama GDP setiap daerahnya, Investor dapat memilih Saham Properti milik siapa yang bisa ditanam saham dalam lembaran yang lebih banyak lagi saham lainnya. 


\section{DAFTAR PUSTAKA}

Elcom. 2012. Seri Belajar Kilat Spss16. Penerbit: Andi. Yogyakarta.

Fahmi. Irham. 2015. Manajemen Investasi Edisi 2. Salemba Empat. Jakarta.

Ghozali, Imam. 2013. Aplikasi Analisis Multivariete Program SPSS. Edisi Ketujuh. Badan Penerbit Universutas Diponegoro.Semarang.

Hafiyyan. Harga Properti: Kenaikan 20 \% Per Tahun.http://bisnis.com (diakses tanggal 12 April 2018).

Hartanto. Pengertian properti. http://Joehartanto.com. (diakses tanggal 8 Mei 2018).

Kasmir. 2014. Dasar-dasar Perbankan. Edisi Revisi 2008. PT. Raa Grafindo Persada. Jakarta.

Mankiw, N Gregory. 2016. Makroekonomi Edisi ke Enam. Erlangga. Jakarta.

Sugiyono. 2013. Metode Penelitian Bisnis. Cetakan Ke-15, Metode Penelitian Kualitatif Kuantitatif dan R \&D Alfabeta, Bandung.

Widoatmodjo, Sawidji. 2015. Pengetahuan Pasar Modal Untuk Konteks Indonesia. Elek Media Komputindo, Jakarta. 